\title{
Z wycieczki na Wschód. O innej Europie oraz o gatunkowej płynności listu w korespondencjach podróżniczych Henryka Sienkiewicza ${ }^{1}$
}

\author{
Jolanta Sztachelska
}

(Uniwersytet w Białymstoku)

\section{DWIE WYCIECZKI}

W sobotni wieczór 2I sierpnia I886 roku Sienkiewicz swoim zwyczajem siadł do pisania listów. Swej stałej korespondentce Jadwidze Janczewskiej donosił z Kaltenleutgeben:

\Przed godziną skończyłem Potop i właśnie podpisywałem pożądany wyraz: „Koniec”, gdy zadzwoniono na kolację. - Leży przede mną trzynaście ostatnich kartek - trzeba tylko jeszcze jutro przejrzeć i wyprawić. Cała kilkuletnia robota jest już za mną, a przede mną - bo ja wiem co? Jak na teraz to pustynia, a raczej próżnia, bo w tej chwili nie ma ani jednej farby na mojej palecie².

Był bardzo zmęczony. W ciągu kilku zaledwie lat napisał nie tylko największą $\mathrm{z}$ dotychczasowych swoich powieści (Trylogię) - w tym momencie jeszcze nieukończoną, ale także zdążył zaznać szczęścia małżeńskiego, poznać smak ojcostwa oraz - doświadczyć tragedii. Matka jego dzieci, Maria z Szetkiewiczów, po nierów-

1 Artykuł powstał w ramach projektu badawczego Henryk Sienkiewicz. Obecność w kulturze polskiej XX wieku. Polskośc i nowoczesność. Recepcja i nowe odczytania. NCN/DEC-2012/06/A/HS2/00252.

2 H. Sienkiewicz, Listy, pod red. J. Krzyżanowskiego, oprac. M. Bokszczanin, konsult. M. Korniłowicz, Warszawa 1996, t. 2, cz. 1-3 (Listy do Jadwigi i Edwarda Janczewskich). Cytat z listu do Jadwigi Janczewskiej, t. 2, cz. 1, list 18, s. 170, (W przytoczeniach zachowano pisownię oryginału). 
nej walce $\mathrm{z}$ nieuleczalną chorobą zmarła w październiku 1885 roku, jeszcze przed ukończeniem I tomu Potopu. List, o którym mówimy, i jego koperta miały czarną obwódkę. Korespondencja z Janczewską, siostrą Marii, zupełnie do niej niepodobną, w której na próżno szukał odbicia tamtej, przedwcześnie zgasłej, staje się dla Sienkiewicza nałogiem, koniecznością, a nawet obsesją. Trwać będzie z górą 30 lat.

Następny zachowany list $z$ tej korespondencji pochodzi z 9 października tego samego roku. To list $\mathrm{z}$ drogi - Sienkiewicz jest już w podróży. Pisze do Janczewskiej z Bukaresztu, w którym przebywa w towarzystwie dwóch przyjaciół: malarza Kazimierza Pochwalskiego oraz znanego dziennikarza warszawskiego Antoniego Zaleskiego. Zwłaszcza ten drugi wydaje się interesujący, bo z tej samej wyprawy, na którą wybrał się niemal w ostatniej chwili ${ }^{3}$, napisał osobną książkę. Nosi ona tytuł $Z$ wycieczki na Wschód ${ }^{4}$ i stanowi relację alternatywną do tej, która wyłania się z korespondencji Sienkiewicza. O tekście Zaleskiego powiedzielibyśmy dzisiaj: książka reportażowa. Składają się na nią i bieżące spostrzeżenia podróżującego, i obfite notatki z dzieł, które dziennikarzowi pozwalały pogłębić doraźne obserwacje oraz wzbogacić opowieść. Objętościowo także jest niemała - liczy sobie ok. 400 stron, szkoda, że nie ma w niej ilustracji czy zdjęć. Zdaje się, że ro lat później powszechnie już używany aparat fotograficzny ${ }^{5}$ wtedy jeszcze wydawał się zbytkiem. Ale być może powód tego braku jest inny - wyjazdowi towarzyszyły pośpiech i nerwowość, wynikające $z$ niepokojących doniesień o sytuacji politycznej na Bałkanach, przez które podróżnicy mieli przejeżdżać. Zarówno Zaleski, jak i jego relacja przydadzą nam się w tej opowieści o Sienkiewiczowskiej wyprawie tym bardziej, że pisarz pozbawił nas przyjemności obcowania $\mathrm{z}$ większym tekstem. Bo najdziwniejsze jest w tym wszystkim, że właściwie tej jego relacji z wyprawy na Wschód nie mamy! $Z$ całej wycieczki, wiodącej przez ogarnięte w I886 roku wrzeniem politycznym ziemie, dzisiejsze tereny Rumunii i Bułgarii, Konstantynopol i Grecję, Sienkiewicz opublikował tylko niewielkie sprawozdanie Wycieczka do Aten i to dopiero w I889 roku! ${ }^{6}$ Dlaczego? Czy coś tu się stało? Dlaczego dopiero wtedy? Oczywiście, wycieczka wydała plon obfity - ale zupełnie innego rodzaju. W Panu Wotodyjowskim pisarz maluje w całym kolorycie turecką potęgę w zmaganiach z Rzecząpospolitą. Dlaczego jednak nie porwał się na opublikowanie własnej korespondencji

3 Dowiedział się o niej, jak pisze we wstępnej części książki, niemal przypadkiem, w Zakopanem, w sierpniu lub na początku września 1886 roku.

4 A. Zaleski, Z wycieczki na Wschód. Notatki dziennikarza. Bukareszt. Ruszczuk. Warna. Konstantynopol, Warszawa 1887.

5 Sienkiewicz, wyprawiając się w grudniu 1890 roku do Afryki, zabiera ze sobą aparat fotograficzny, dzisiaj w Muzeum Henryka Sienkiewicza w Oblęgorku.

6 Wycieczka do Aten, „Niwa” 1889, nr 1-5. Cyt. wg przedruku: H. Sienkiewicz, Dzieta, pod red. J. Krzyżanowskiego, t. 44, Warszawa 1950. 
z podróży? $\mathrm{Na}$ razie musi to pozostać w sferze domysłów. Chyba że uznamy za prawdę to, co ujawnia Zaleski we wprowadzeniu do swojej książki. Że jeden pojechał po materiał dziennikarski, a drugi - po wrażenia artystyczne.

\section{Kiedy PRyWATne staje się PUbliczne}

I tak jesteśmy w lepszej sytuacji niż dziewiętnastowieczni czytelnicy Sienkiewicza, którzy wiedząc o wyprawie pisarza, na próżno wyczekiwali jakiegoś jego tekstu. Tę lukę mogło wypełnić w pewnej części sprawozdanie Zaleskiego, drukowane po powrocie z podróży w grudniu I886 oraz w styczniu i lutym i887 roku w „Słowie”, piśmie, które ciągle kojarzono $\mathrm{z}$ autorem Trylogii, choć już wtedy należał do jego redakcji tylko formalnie. Relacja Sienkiewicza zachowała się w pełni tylko w listach prywatnych do Jadwigi Janczewskiej, dostępnych dzięki opracowaniu obszernej epistolograficznej spuścizny autora Trylogii przez niestrudzoną Marię Bokszczanin7. Listy do szwagierki pisarza to nie tylko jedna z najciekawszych części tej całości, ale prawdopodobnie jedyny taki zbiór w całej literaturze polskiej. Nie chodzi o obszerność, są bowiem kolekcje większe, np. korespondencja Józefa Ignacego Kraszewskiego. Decydujące wydaje się jej znaczenie dokumentarne i literackie. Po pierwsze, listy te zastępują inne dokumenty osobiste pisarza $z$ tego okresu, po drugie - są osobnym, wartym uwagi dokonaniem artystycznym; pod tym względem trudno znaleźć coś, co mogłoby się z nimi równać.

W październiku I889 roku Sienkiewicz pisał do swojej adresatki z powinszowaniem imienin i donosił, że zakupił właśnie dwa kajety z przeznaczeniem na pamiętnik. Planowal, że znajdzie się w nim miejsce i dla niej - pieszczotliwie nazywanej Dzinią, Dzidką lub - z powodu szeroko rozstawionych oczu - Żabą, a nawet „Ziabą”. „Muszę wziąć jednak - dodawał - bardzo cienką stalówkę, żeby oddać te wszystkie finezje - przy czym radzę, żeby Żaba była dobra dla Toma, bo inaczej uczerni" ". Tom to szekspirowska figura, którą często stosował wobec samego siebie - Tom, albo Poor Tom, to żebrak i błazen, ktoś, komu „ciągle zimno”, ale - $\mathrm{w}$ istocie - książę w przebraniu, następca tronu, niesłusznie przez uzurpatora pozbawiony zaszczytów. Ten kostium, zaczerpnięty z Króla Leara, odgrywał w prywatnym teatrze Sienkiewicza szczególną rolę w relacjach z kobietami - najpierw

7 Edycja spuścizny epistolograficznej Sienkiewicza ukazywała się w latach 1977-2009 (tomy 1-5) i, wedle słów autorki opracowania, jest nieukończona. Odnajdują się co prawda tylko pojedyncze listy, ale na druk czekają także listy do Sienkiewicza, których znajomość pozwoliłaby na wyjaśnienie wielu nieznanych jeszcze kwestii biografii i twórczości pisarza. Listy do Jadwigi Janczewskiej w edycji znajdują się w t. 2 (cz. 1-3).

8 H. Sienkiewicz, Listy, op. cit., t. 2, cz. 2, list 183, s. 129. 
z Marią, pierwszą żoną, a po jej śmierci z Jadwigą, jej siostrą. Z rzadka, i tylko w wyjątkowych sytuacjach, pojawiał się w wypowiedziach publicznych jako sygnał niezgody na rzeczywistość 9 .

Pamiętnik nie dotrwał do naszych czasów, listy tak. I tylko dzięki nim otrzymujemy jedyny w swoim rodzaju portret podwójny: najpierw adresatki - powiernicy, czułej przyjaciółki, niekiedy także surowego cenzora („Jankulia”o), mającego niebagatelny wpływ na estetyczne decyzje autora, potem - pisarza, który, choć może nie do końca szczery, a z pewnością nieekshibicjonistyczny, pisze Jadwidze o wszystkim, co przydarza się w jego życiu, wcale nie tak barwnym, jak to postrzega narosła po jego śmierci legenda. Nade wszystko zaś listy do Janczewskiej są pierwszym i autentycznym przekazem tego wszystkiego, co Sienkiewicz zobaczył i przeżył w podróży. W tym przypadku, który nas interesuje, a potem także w przypadku wycieczki do Hiszpanii, potwierdza się intuicja, że pisanie do szwagierki traktował jako pisarską przed decyzją o ewentualnym druku swoich wrażeń. Wydarzenie relacjonował na gorąco, czasem nawet $\mathrm{w}$ kilku wersjach ${ }^{\mathrm{II}}$, dając ją pod osąd respondentki, potem zaś poprawiał i dopełniał. Niekiedy jednak rezygnował z publikacji całości, zostawiał to tylko, co wydawało się kwintesencją podróży, było nacechowane jakąś szczególną intencją lub - po prostu - wydawało się najbardziej interesujące. Dotyczy to w szczególności wyprawy na Wschód z I886 roku, z której ocalało tylko sprawozdanie z Grecji (Wycieczka do Aten) oraz nieznanej bliżej podróży Sienkiewicza do Hiszpanii, z której mamy Walkę byków $w^{\mathrm{I2}}$. Rezygnacja z upublicznienia wrażeń mogła wynikać również z innych powodów. Być może autor uznał, że tekst nie jest jeszcze gotowy, mogło mu także zabraknąć czasu - kalendarz powieściopisarza był ściśle

9 Takim momentem szczególnym wydaje się pierwszy felieton Sienkiewicza po powrocie z Ameryki z 1879 roku. Niepewny sytuacji, w którą się pakował, rozedrgany jeszcze wewnętrznie po długim pobycie za granicą, z niechęcią podejmował dziennikarskie zobowiązania w „Niwie”, która pod jego nieobecność mocno skręciła na prawo. Pisał tak: „Nie mam żadnych powodów do dobrego humoru; jestem raczej jak ów Tomek z Króla Leara, bo zimno mi pod każdym względem. Rzeczywistość, z którą musi mieć do czynienia kronikarz, jest jak zwykle: szara, bezbarwna, smutna, często jałowa - niech więc uprawia sobie tę rolę, kto chce; ja nie mam sił, ochoty i będę mówił o czym innym". Z komentowania „Chwili obecnej” przenosił się do „Mieszanin literacko-artystycznych” - świata „myśli i wyobraźni”. Cyt. H. Sienkiewicz, Mieszaniny literacko-artystyczne (I), w: idem, Dzieta, pod red. J. Krzyżanowskiego, t. 50, Warszawa 1950, s. 3-4 (w cytacie stosuję zapis oryginału).

10 Jankulio to prawdziwe nazwisko urzędującego wówczas w Warszawie rosyjskiego cenzora.

11 To przypadek chyba nieodosobniony. Do naszych czasów zachowały się np. dwie wersje jednego listu z Aten. Zob. H. Sienkiewicz, Listy, op. cit., t. 2, cz. 1, list 32, zob. s. 260-271.

$12 \mathrm{~W}$ przypadku wyprawy do Hiszpanii luka wydaje się wyjątkowo intrygująca, bo Sienkiewicz spędził tam aż 40 dni i odwiedził najciekawsze miasta na Półwyspie Iberyjskim. Planował stamtąd także wycieczkę do Tangeru (Maroko), nie doszła jednak do skutku z nieznanych nam przyczyn. Wybrane partie korespondencji prywatnej ogłosił Julian Krzyżanowski w 1931 roku w „Kurierze Warszawskim" (nr 1) pt. Niedrukowane listy Sienkierwicza. Z podróży do Hiszpanii, nie ujawniając zresztą, że pochodzą z prywatnej korespondencji.

$\mathrm{Na}$ temat podróży oraz szkicu Walka byków zob. J. Sztachelska, Henryk Sienkiewicz. Życie na walizkach, Warszawa 2017, s. 93-99. 
zapełniony, priorytet stanowiła zawsze praca literacka. Tekst dziennikarski z powodów oczywistych bardziej niż jakikolwiek inny zapis ulega dezaktualizacji. Chyba że jest wyjątkowy.

\section{Butgarskie AWANTURY ALbo gDZIE JEST Wschód?}

Wycieczka Sienkiewicza zaczęła się dokładnie 6 października I886 roku wyjazdem z Krakowa i prowadziła do Konstantynopola via Bukareszt i Warna. Była ryzykowna - tereny dzisiejszej Bułgarii i Rumunii (także Bośni i Hercegowiny), przez które wiodła jej trasa, od I876 roku znajdowały się w stanie permanentnego politycznego fermentu. Konsekwencją zwycięstwa Rosji w wojnie z Turcją było wyłonienie się nowych organizmów państwowych. Wraz z utworzeniem w I879 roku Księstwa Bułgarii i wstąpieniem na tron księcia Aleksandra Battenberga $z$ dynastii heskiej kryzys polityczny wydawał się zażegnany. Państwa centralne nie kryły jednak niezadowolenia z powodu rozwoju nowego państwa. Rosja jako potęga, która wyzwoliła Słowian z przeszło pięćsetletniego panowania tureckiego, miała tam bowiem wielu zwolenników i własne interesy. Tak doszło do tzw. wojny serbsko-bułgarskiej (listopad 1885 roku), wyraźnie sprowokowanej przez Austro-Węgry. Później, jesienią r886 roku, kiedy miał zebrać się parlament nowego państwa bułgarskiego, na jego terenie doszło do licznych prowokacji ze strony stronnictwa prorosyjskiego i nasłanych z Rosji szpiegów. Wyjeżdżających z Polski dobiegła wiadomość o detronizacji księcia Battenberga.

Dokładną trasę podróży Sienkiewicza i jego towarzyszy znamy dzięki korespondencji z Jadwigą Janczewską i małżeństwem Gropplerów, u których podróżnicy zatrzymali się w Konstantynopolu. Niezbędnym źródłem są wspomnienia Antoniego Zaleskiego, opisujące najrozmaitsze perypetie wspólnej wyprawy, wypełnione szczegółowymi informacjami na temat aktualnych kwestii politycznych, ciekawostkami historycznymi oraz rozważaniami z zakresu ekonomii. Zaleski mocno zadłuża się tutaj u wielu autorów, w sposób zaś szczególny u Emila de Laveleye’a, z którego prac korzysta obficie w swoich zapiskach ${ }^{\mathrm{I}}$. Polacy podróżują głównie koleją -9 października zatrzymują się w Bukareszcie, następnego dnia w bułgarskim Ruse (Ruszczuku4), a I3 października w Warnie, gdzie zamierzają przesiąść się na statek do Turcji.

13 Emile de Laveleye (1822-1892), ekonomista belgijski, prof. ekonomii politycznej Université de Liège w szczególności interesował się związkiem pomiędzy ekonomią i polityką. Opublikował m.in. prace: La Russie et L'Autriche depuis Sadowa (1870), Essais sur les formes de gouvernement dans les societes modernes (1872). W Europie wielkim zainteresowaniem cieszyła się jego praca La Péninsule des Balkans (1887-1888), opublikowana także w języku angielskim, dotycząca m.in. fenomenu przetrwania pod zwierzchnictwem Turcji „małych” narodów słowiańskich, w tym Rumunii i Bułgarii.

14 Sienkiewicz posługuje się nazwą Ruszczuk (Rusczuk), którą stosowano od czasów tureckich, czyli od XVI wieku. 
Wypełnione aluzjami politycznymi i rysunkami listy Sienkiewicza, od dawna zainteresowanego przyszłością tego europejskiego regionu ${ }^{15}$, stanowią ciekawy dokument tego czasu. Podróżnicy z bliska przyglądają się bułgarskim awanturom. My zaś mamy okazję wejść w scenerię, w której jakiś realny Wokulski robi na tych awanturach krociowe interesy ${ }^{16} . \mathrm{Z}$ listów pisarza wynika, że podglądanie historii dziejącej się na ich oczach jest fascynujące. Pisze do szwagierki: „Dzinka stanie się z czasem biegłą w kwestii wschodniej”, w pewnym momencie zaczyna ją także tytułować „najmilszą Ekscelencją ${ }^{\text {”7 }}$. Równie podminowany jest Zaleski, obdarzony sporym dziennikarskim temperamentem. Sienkiewicz pisze o nim: „Antał jest w swoim żywiole. Lata, zbiera nowinki i przylatuje co chwila $\mathrm{z}$ wybuchami śmiechu i z opowiadaniem, machając rękoma i napierając mnie tak blisko swoją cyrkumferencją, że się muszę opędzać" ${ }^{8}$.

Obaj z nieukrywaną satysfakcją obserwują rozwój wypadków. Bułgarzy, choć prowokowani i wodzeni na pokuszenie przez Rosję, jak zawsze zainteresowaną rozbudową swojej sfery wpływów, wykazują zadziwiający spokój i wstrzemięźliwość. Manipulacje Kaulbarsa ${ }^{\mathrm{I} 9}$ spełzają na niczym. Sienkiewicza cieszy więc polityczny rozsądek braci Słowian. Tu, w Bułgarii i Rumunii, notuje: „Nienawiść do «matuszki» powszechna”2o. Według jego opinii mieszkańcy tych krajów, doświadczeni wielowiekową niewolą, dojrzeli już do zmiany. Kilkusetletnia zależność polityczna od Turcji, aktualnie zaś od Rosji, odcisnęła na nich swoje piętno, blokując normalny rozwój, ale powszechnie czuje się pragnienie wolnego życia. Czytamy w relacji:

\section{\jakkolwiek jest to mieszanina, Europejczyk [...] nie wsiąka w nią i nie staje się jej częścią składową. Sam czuje się obcym i ci ludzie $\mathrm{w}$ fustangach ${ }^{2 \mathrm{I}}$, w kaftanach, w fezach i czapkach baranich uważaja go za obcego. Jakkolwiek różni między sobą, stanowią w przeciwień-}

15 Pisarz po raz pierwszy dał upust tym swoim zainteresowaniom w relacji z Wenecji, do której udawał się przez Dalmację i Ilirię w październiku 1879 roku. Zob. mój tekst Italia Henryka Sienkiewicza, w: J. Sztachelska, Mity sienkiewiczowskie i inne szkice tylko o nim, Warszawa 2017.

16 Jak wiadomo, Lalka zaczyna się od słynnego zdania („W początkach roku 1878...”) i powrotu Wokulskiego z Bałkanów.

17 H. Sienkiewicz, Listy, op. cit., t. 2, cz. 1, list 22, s. 196, 194.

18 Ibidem, list 20, s. 179.

19 Kaulbars, właśc. Nikołaj Wasiljewicz Kaulbars (1844-1925), generał rosyjski, uczestnik wojny rosyjsko-tureckiej w roku 1877. W 1883 roku brał udział w zawieraniu ugody między Rosją i Bułgarią, w 1886 roku wysłany jako delegat dyplomatyczny w celu opóźnienia wyborów do Sobranja i przekonania Bułgarów o konieczności protektoratu Rosji. Ponieważ jego wysiłki spełzły na niczym, opuścił Bułgarię wraz z całym korpusem dyplomatycznym.

20 H. Sienkiewicz, Listy, op. cit., t. 2, cz. 1, list 20, s. 179.

21 Fustanga - prawdopodobnie zniekształcona przez Sienkiewicza nazwa sukni męskiej noszonej na Bałkanach i w Grecji. Nazwa urobiona od łac. fustagna. W innej wersji - fustanella. 
stwie do Franków [Europejczyków zachodnich - J. Sz.] Wschód, mahometański czy grecki, ale odrębny. I co więcej: nawet tak krótki pobyt tu narzuca przekonanie, że Półwysep Bałkański musi z czasem należeć do ludów bałkańskich ${ }^{22}$.

To tylko kwestia czasu, pisarz odruchowo czuje solidarność wobec spragnionych wolności. Obcy muszą stąd odejść:

\section{\Rosja czy Anglia, czy Austria mogą na czas, może długi, pochwycić części tego półwyspu - ale wobec coraz wyraźniejszych aspiracji i po- czucia narodowego w aborygenach, na zawsze się tu nie ostoją. Jestem prawie pewny, że np. Bulgaria nie może być już zmieniona w prostą gubernię rosyjską ${ }^{23}$.}

Spojrzenie Sienkiewicza jest doskonale zewnętrzne. Nie zna miejscowych języków - rumuńskiego czy bułgarskiego, rosyjski, choć dość rozpowszechniony, okazał się w tym burzliwym okresie dość niebezpieczny, podobnie jak fakt, że podróżowało się na rosyjskim paszporcie. Choć według zachodnich standardów przybywa ze wschodu Europy, czuje się raczej przedstawicielem kultury i cywilizacji Zachodu. Czy słusznie? I skąd ta pewność? Czyżby dawała ją przynależność do galaktyki artystów i pisarzy, w których od zawsze siebie umieszczał? Wydaje się, że tak. Sienkiewicz od początku wierzył, że artyści mają dwie ojczyzny - tę, w której się urodzili, i tę, z której tradycji czerpią swoją inspirację ${ }^{24}$, dla niego była nią kultura grecko-rzymska. Ale pisarz w żadnym miejscu nie prezentuje swojej wyższości wobec spotykanych ludzi. Doświadczenie podróżnika nauczyło go pokory i ostrożności w spotkaniu z Innym. Ma za sobą tak istotną w lekcji rozumienia cywilizacji czy odmienności podróż amerykańskąa ${ }^{25}$.

Z drugiej strony, ludy zamieszkujące Półwysep Bałkański (określane jako Turcja europejska) niezmiernie długo, w XIX wieku, a nawet jeszcze w XX (zwłaszcza po konflikcie w latach osiemdziesiątych), często postrzegane są przez Zachód jako reprezentanci innego, gorszego świata, jakiejś nieznanej ucywilizowanym „dzikiej Europy”, eksplodującej niewyobrażalną skalą konfliktów politycznych, barba-

22 H. Sienkiewicz, Listy, op. cit., t. 2, cz. 1, list 22, s. 196.

23 Ibidem.

24 Pisze o tym wprost do Jadwigi Janczewskiej 18 grudnia 1895 roku. Zob. H. Sienkiewicz, Listy, op. cit., t. 2, cz. 3, s. 173.

25 Zob. mój tekst Ameryka - dotknięcie Nowego Świata, w: J. Sztachelska, Mity sienkierwiczowskie, op. cit. 
rzyństwa i stereotypów utrwalonych w popkulturze ${ }^{26} . \mathrm{Tu}, \mathrm{w}$ przestrzeni Orientu, intensywniej niż gdzie indziej, „wszystko co stałe rozpływa się w powietrzu” ${ }^{27}$. Dokonująca się na Półwyspie Bałkańskim po odejściu Turcji w drugiej połowie XIX wieku modernizacja, a właściwie jakiś proces wtórnego „ucywilizowania”, przybrała charakter nie restytucji tego, co oryginalne, ale zniwelowania tego, co orientalne, miejscowe, i wszechobejmującej imitacji obcych wzorów - w architekturze, kulturze, obyczajach. Proces ten wychwytuje w swojej relacji Zaleski, który, podobnie jak Sienkiewicz, pisze o dziwnej, chaotycznej zabudowie Bukaresztu, pomieszaniu stylów - bizantyńskiego i metropolitalnego oraz zalewającym ulice błocie. Jego uwadze nie umknęła także rumuńska socjeta, groteskowo imitująca towarzyskie rytuały Francuzów i Anglików, zupełnie zaś bezradna wobec wyzwań nowoczesnej ekonomii. Dla dziennikarza Wschód zaczął się gdzieś za Czerniowcami, gdzie zamiast ubogich chat galicyjskich chłopów coraz częściej pojawiały się... dziury w ziemi, w których w niewyobrażalnie prymitywnych warunkach żyją Wołosi, Rumuni i inni mieszkańcy tej urodzajnej, ale zupełnie niezagospodarowanej ziemi. O Bułgarii Zaleski pisze w pewnym momencie: „Ekonomiczny stan dzisiejszej Bułgarii porównują zwykle z tym, w jakim znajdowała się cała Europa w epoce Karola W[ielkiego] i w jakim znajdują się dziś jeszcze Indie Wschodnie”28. Ale Bułgarzy i tak wypadają w jego opinii lepiej niż inni, bo jako europejscy „ogrodnicy” wykorzystują ile się da nawet najmniejsze skrawki ziemi pod uprawę. Rumunia, pisze dziennikarz, mogłaby być zasobnym krajem, taką Lombardią środkowej Europy, gdyby miała inne stosunki agrarne, jakąś tradycję gospodarowania i postawiła na oświatę. Zwłaszcza wieś robi tutaj wstrząsające wrażenie:

\section{\Negrowie Afryki środkowej lepiej chyba mieszkają i osady ich weselszy przedstawiają widok. [...] I w tych to lepiankach rzuconych na istnej}

26 To postrzeganie przez innych, zazwyczaj podróżników z Zachodu, nieznających języków i niewchodzących głęboko w kulturę, jest przedmiotem znakomitej książki Božidara Jeziernika Dzika Europa. Batkany w oczach zachodnich podróżników (Kraków 2007), napisanej w duchu postkolonializmu. Równie ciekawy obraz innego świata prezentuje książka Błażeja Brzostka Paryże Innej Europy. Warszawa i Bukareszt, XIX i XX wiek (Warszawa 2015). Popkulturowe uproszczenia to np. rozumienie Rumunii przez pryzmat postaci wampirów, które romantyzowana, frenetyczna wyobraźnia Brama Stokera umieszczała w niedostępnych przestrzeniach górzystej Transylwanii.

27 Książka Marshalla Bermana („Wszystko co state rozptywa się w powietrzu”. Rzecz o doświadczeniu nowoczesności, Kraków 2015) dotyczy procesu modernizacyjnego, który według niego inaczej realizowany był na zachodzie Europy, inaczej zaś w Rosji. To, co Berman pisze o Rosji Dostojewskiego, znajduje analogię w powieści polskiej drugiej połowy XIX wieku, z pewnością w Lalce (pierwodruk czasopiśmienniczy 1887-1889) Bolesława Prusa („Ależ tu jest więcej marmurów - mówi Wokulski w Paryżu - aniżeli w całej Warszawie!”), ale także w Wysadzonym z siodta (1891) Antoniego Sygietyńskiego.

28 A. Zaleski, op. cit., s. 157. 
pustyni żyją potomkowie kolonów Trajana, od siedemnastu wieków osiadłych na tej najurodzajniejszej w całej Europie glebie ${ }^{29}$.

\section{WśróD SWOICH}

W czasie podróży zdarza się wiele komicznych sytuacji, współtowarzysze świetnie się ze sobą bawią. Zaleski i Pochwalski w listach Sienkiewicza z Rumunii figurują jako Zalescu i Pochwalcescu i otrzymują nader dowcipne portrety. Energia dziennikarza, biegającego za nowinkami, jest kontrastowana z nieśmiałością malarza, który nie bierze w dyskusjach udziału, skupiony na rysowaniu i wychwytywaniu miejscowego kolorytu.

W drodze wiele rzeczy Sienkiewicza zaskakuje. Już w Bukareszcie zanotował:

\Z Zabawne to jest, że wszędzie mówi się po polsku. Przyjeżdżamy do Suczawy - wołam na posługacza: „Ojciec, weźcie pakunki.”- Antał wybucha śmiechem, a posługacz odpowiada: „Zaraz, panie!”-W bufecie po polsku: „Pieczeń wołowa!”- W paczkarni po polsku, w Romanul także ${ }^{30}$.

To fakt, wszędzie na całej trasie podróżnicy spotykają wielu Polaków, którzy rozjechali się po całym świecie za pracą. Nie brak ich także na Bałkanach. Emigracja zdolności jest niestety faktem ${ }^{3 \mathrm{I}}$. W kraju „wykształceni” i „niepotrzebni””2 ${ }^{2}$, na emigracji zajmują nieraz bardzo odpowiedzialne stanowiska. W Rumunii i Bułgarii personel zarządzający i inżynierowie na kolei to przeważnie Polacy. Podobnie jest na poczcie, w hotelach i restauracjach. W Warnie Sienkiewicz zwiedza pole bitwy i pałac książęcy w towarzystwie świeżo poznanych ludzi:

\ ledwośmy się poznali z Wróblewskim, gdy ten zwraca się do jakiegoś Turka w fezie, czerwonych papuciach i [o] wilczej mordzie i mówi do niego najczystszą polszczyzną: „Hassan! Weźmiesz rzeczy panów, zawieziesz do hotelu i będziesz na mnie czekał”. A Hassan na to również po polsku: „A drugą dorożkę dla panów zamówić? bo później poodjeżdżają". Rety! co to za Hassan, co umie po polsku? - pytam.

29 Ibidem, s. 23.

30 H. Sienkiewicz, Listy, op. cit., t. 2, cz. 1, list 19, s. 174.

31 Emigracja zdolności to tytuł słynnego artykułu Elizy Orzeszkowej z 1899 roku, podejmującego problem emigracji Polaków nieznajdujących dla siebie w kraju możliwości samorealizacji.

32 Zob. klasyczną pracę Jerzego Jedlickiego Jakiej cywilizacji Polacy potrzebuja, Warszawa 1988, rozdz. Potrzebni i zbędni. 
I cóż się pokazuje? Oto jest Tatar, mahometanin, który u Czajkowskiego nauczył się po polsku tak jak Polak ${ }^{33}$.

Tak oto na Bałkanach krzyżują się cienie Sadyka Paszy i Wokulskiego.

Dotarłszy do Warny, podróżnicy nie marnują czasu i szybko dostają się na rosyjski statek „Oleg”. Sienkiewicz swoim zwyczajem wyraża wiele obaw, bo nazwa statku... niebezpiecznie się rymuje z „poległ”. Wbrew tym wisielczym prognozom jeszcze tej samej nocy docierają do Konstantynopola, ale tu okazuje się, że wcześniejsze hiobowe zapowiedzi długiej kwarantanny potwierdzają się w całej rozciągłości. Ze względu na groźbę zarazy (cholery? tyfusu?) podróżnicy zmuszeni są do odbycia dziesięciodniowego postoju w porcie. Nie są tym uszczęśliwieni, doskwiera im nuda, wzrastają koszta podróży, ale innego wyjścia nie ma. Stoją w Kawak, a więc na przedmieściu Konstantynopola. Sienkiewicz w tym czasie zgłębia przewodniki i intensywnie robi notatki, Zaleski, podobnie, obczytuje się porządnie w pracach na temat Konstantynopola i porządkuje zapiski - wszystko może się przydać. Pochwalski opracowuje wcześniejsze szkice. Po dziesięciu dniach wyczekiwania wreszcie są na miejscu. W Konstantynopolu wita ich Henryk Groppler, polski emigrant od lat żyjący nad Bosforem. On i jego żona Ludwika, o których Sienkiewicz pisze: „Jacyś przedpotopowej uprzejmości ludzie", będą przyjmować pisarza i jego kompanów przez dwa tygodnie w swojej obszernej willi, wypełnionej dywanami, kobiercami, najrozmaitszymi obiektami sztuki orientalnej („w całym mieszkaniu - donosi Sienkiewicz Janczewskiej nie ma ani jednego zwyczajnego mebla") ${ }^{34}$, kolekcją broni oraz zamieszkałej, jak skrzętnie odnotowuje, przez co najmniej... 40 kotów. Jadwiga jest ich miłośniczką.

\section{MIRAGE ORIENTAL?}

Już podczas podróży przez Półwysep Bałkański Sienkiewicz, spragniony egzotyki, wyczulony na koloryt wschodni, gorączkowo poszukiwał wrażeń - malowniczych pejzaży, miejskich zaułków, budowli sakralnych, a w szczególności orientalnych „fizjognomii”. Szukał charakterystycznych zachowań, odmiennego stylu życia. Jego uwagę przyciągnęły haftowane koszule bułgarskich dziewcząt, baranice na głowach i albańska fustanela ${ }^{35}$. Dostrzegał dojmujące ekonomiczne kontrasty i wszechobecną nędzę. Zwracał uwagę na najdrobniejsze objawy inności - i zawoje na głowie,

33 H. Sienkiewicz, Listy, op. cit., t. 2, cz. 1, list 22, s. 197.

34 Ibidem, list 25, s. 208 i list 26, s. 212.

35 Zob. przypis 21. 
i dzikie oczy, i nadzwyczajny ruch w porcie, i powszechny zwyczaj bakczyszu. Jesteśmy wszak na Wschodzie! Już w Ruszczuku wychwytywał pewne znamiona orientalizacji życia. Stwierdzał żartobliwie: tu to prawie jak u nas, tylko ludzie poprzebierani jacyś - jak w karnawale, twarze charakterystyczne, „rozbójnicze”. $\mathrm{W}$ jednym $\mathrm{z}$ listów zapewniał:

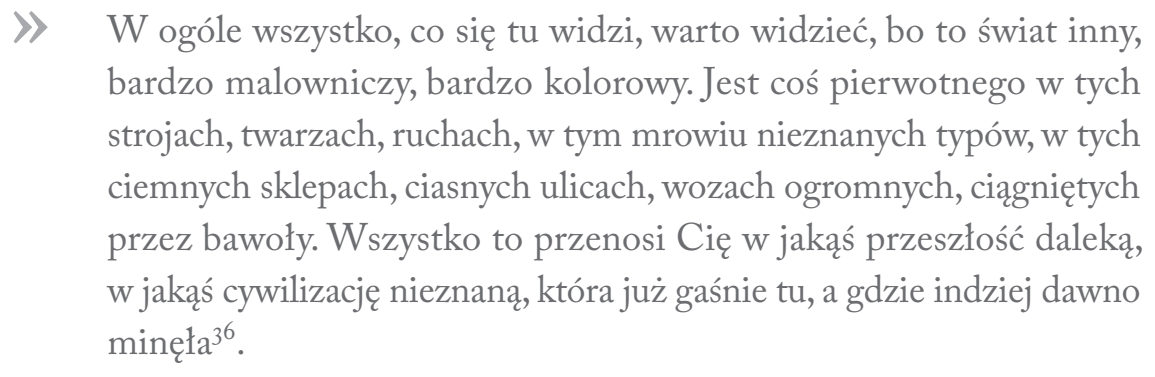

To bardzo znamienny komentarz, odbijający poglądy kogoś, kto jest nie tylko z innego świata, ale także z innej cywilizacji, tej, która z pewnością „nie odchodzi” i która, w odróżnieniu od tej, którą z takim zainteresowaniem tropi, szybko „nie minie”. To przekonanie nie jest jedynie refleksem aktualnej sytuacji politycznej na Bałkanach, przechodzących poważne zmiany, ale czymś trwałym, czemu pisarz dawał wyraz bardzo wcześnie, już w trakcie pracy nad tzw. małą trylogią, w której portretował tak bliskich mu ze względu na swoje pochodzenie Tatarów ${ }^{37}$. Ujawnia się w tych uwagach jego pogląd na społeczno-kulturową rolę islamu. W trakcie rejsu statkiem z Warny do Konstantynopola Sienkiewicz bacznie obserwował społeczność turecką, podkreślając malowniczość ich religijnych obrzędów, przywiązanie do tradycji, intensywność wiary:

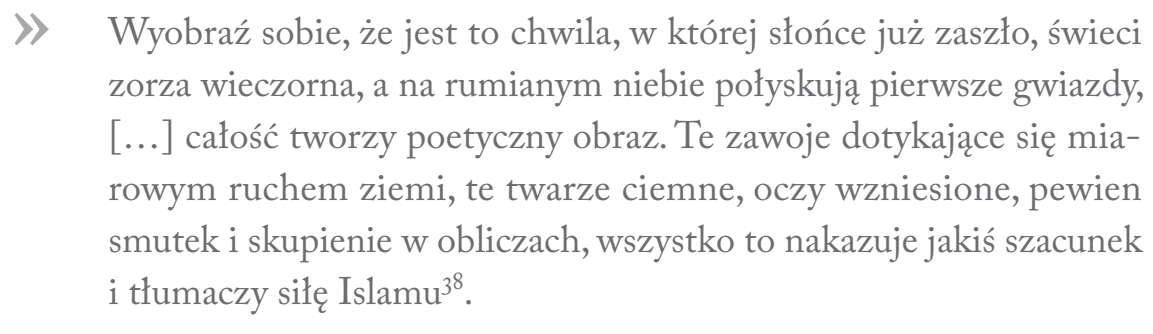

36 H. Sienkiewicz, Listy, op. cit., t. 2, cz. 1, list 20, s. 183-184.

37 Swojego tatarskiego pochodzenia co prawda Sienkiewicz nie eksponował, ale wątki tatarskie wyjątkowo często pojawiają się w jego twórczości. Na temat jego pochodzenia piszę w rozdziale Tatarzy Henryka Sienkiewicza, w: J. Sztachelska, Mity sienkiewiczowskie, op. cit. Temat stosunku pisarza do islamu podejmuje Maciej Gloger w artykule Islam i dekadencja w twórczości Henryka Sienkiewicza, wygłoszonym w listopadzie 2016 na konferencji Henryk Sienkiewicz. Voyager dans le temps et lèspace zorganizowanej przez Stację Badawczą PAN i Bibliotekę Polską w Paryżu.

38 H. Sienkiewicz, Listy, op. cit., t. 2, cz. 1, list 24, s. 204. 
Znamienna wydaje się w tym fragmencie estetyzacja modlitwy, podkreślanie dawności, autentyzmu i powagi. Sienkiewicz jest jednak człowiekiem swoich czasów, pozytywistą i modernistą o wyrazistej proeuropejskiej orientacji. Islam to dla niego cywilizacja przeszłości, niezdolna do funkcjonowania we współczesnym świecie.

Podczas pobytu w Stambule podróżnicy chętnie wypuszczają się w miasto. Pierwsze wrażenia $\mathrm{z}$ tych wizyt nie są jednak pozytywne. Miasto przedstawia im się jako bardzo rozległe, chaotycznie zabudowane i potwornie brudne. Zwiedzają Perę (dzielnica północno-wschodnia), oglądają najważniejsze zabytki Stambułu: meczet św. Zofii, grób Mohammeda, Muzeum Janczarskie, Tysiąc Kolumn, hipodrom, stary Seraj. Będą tu zresztą wielokrotnie, bo nie da się tego wszystkiego zobaczyć za jednym razem. Na pisarzu duże wrażenie wywiera gigantyczna Hagia Sophia:

\O ile św. Piotr w Rzymie wydaje się mniejszy, o tyle ona większą, niż jest. W środku pusta. Ogromne świeczniki roboty bardzo grubej zwieszają się z sufitu nad całą świątynią. W czterech stronach olbrzymie tarcze zielone $\mathrm{z}$ tureckimi napisami zawieszone są wysoko pod kopułą. Kopuła środkowej bazyliki wykładana pozłocistą mozaiką. Zresztą ni ołtarzów, ni jakichkolwiek przedmiotów. Posadzka pokryta słomkowymi matami; kilkunastu wiernych wyśpiewuje sennymi głosami modlitwy, ale nie ma w nich ni tej szczerości, ni tej powagi, którą widziałem u Turków modlących się na statku. Z zewnątrz przybudowano cztery minarety i mnóstwo budowli, które psują całośç3 ${ }^{39}$.

W odróżnieniu od bardzo wtedy popularnego w Polsce de Amicisa ${ }^{40}$, Sienkiewicz zdobywa się na złośliwy komentarz:

\ podług mnie styl bizantyński, choćby najczystszy, nie ma w sobie prostoty romańszczyzny, ani powagi gotyku, ani wdzięku wesołego renesansu. To tak wygląda jakby olbrzymie jakieś płuca wydęły od spodu część skorupy ziemskiej i wytworzyły na jej powierzchni wielki bąbel. Może to bluźnierstwo, ale szczere ${ }^{4 \mathrm{I}}$.

W myśl postkolonializmu z pewnością to bluźnierstwo, przypominające żywo wywody francuskiego pisarza i podróżnika Astolphe’a de Custine’a, który w swoim

39 Ibidem, list 26, s. 215.

40 O de Amicisie (książka tego autora w przekładzie Marii Siemiradzkiej pt. Konstantynopol. Wspomnienia z podróży ukazała się w Warszawie w 1879 roku) często wypowiada się Zaleski, twierdząc, że autor swoje wrażenia tak ubarwił i wyidealizował, że są opisem nie tyle realności, co jakiejś fatamorgany.

41 H. Sienkiewicz, Listy, op. cit., t. 2, cz. 1, list 26, s. 215. 
słynnym opisie podróży ${ }^{42}$, próbując określić, w jakim stylu zbudowano najsłynniejszą cerkiew w Moskwie, nie umiał znaleźć dlań jakiegokolwiek istniejącego w kulturze Europy układu odniesienia. Także Sienkiewicz nie poddał się fatamorganie orientalnego piękna.

Jeszcze gorzej w jego opisach wypadł meczet Mohammeda, jedna z większych atrakcji metropolii nad Bosforem. Sienkiewicz pisze do Jadwigi:

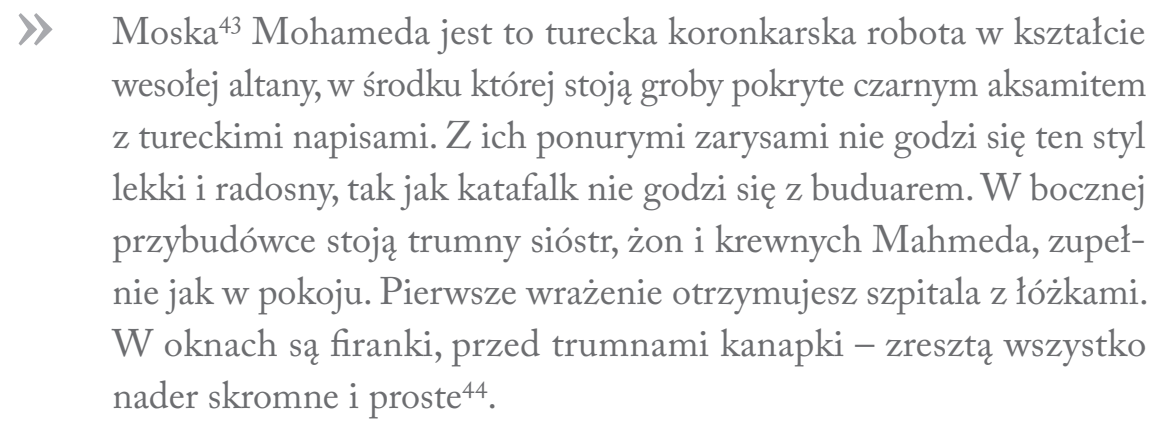

Nie da się ukryć, spotkanie z Konstantynopolem jest dla Sienkiewicza szokiem. Oczekiwał mirage oriental, doświadczył wszechobecnego chaosu, bylejakości i brudu, których skala zdumiała go, przerosła najśmielsze oczekiwania. W tym samym liście czytamy:

\Co to jest Stambuł? Tu i owdzie wielka jakaś budowa: Seraskierat, Wysoka Porta, Św. Zofia, meczet Sulejmana, zresztą nagromadzenie chat nędznych nad wszelki wyraz. Wyobrażałem sobie, że to będą brudy, ale brudy włoskie, wśród których przebłyskują arcydzieła, spiętrzone mury, wśród których widać twarze bogów i duch wielki. Gdzie tam! To nie brudy, tylko obrzydliwości. To nie spiętrzone mury, tylko walące się żydowskie domostwa małego miasteczka. [...]. Góry śmieci, paskudztwa, resztek ubrania, jedzenia, powybijane doły, porozkopywana naga ziemia. Między tym wszystkim i na ulicach psy i psy. Ale nie „dusze złote” - tylko bezkształtne, robaczywe, parszywe, ociekłe potworki, których woń z daleka sprawia mdłości ${ }^{45}$.

42 A. de Custine, La Russie en 1839, Bruxelles 1844.

43 Moska (z franc. mosque) - meczet.

44 H. Sienkiewicz, Listy, t. 2, cz. 1, list 26, s. 215.

45 Ibidem, list 26, s. 216. 
Te zapisy, z dominującym motywem „zdechłych psów na Galacie”, nie są, jak widać, pozbawione aksjologii. Sienkiewicz surowo ocenia cywilizacyjne osiągnięcia imperium, które niegdyś władało połową świata. Dzisiaj - jak sądzi - z tej potęgi nie zostało już nic. Turcja nie może nawet marzyć o porównaniu $z$ niedościgniona w rozwoju Europą Zachodnią. Polemizując z de Amicisem, który Stambuł z zachwytem porównuje do gigantycznej wsi rozrosłej nad Bosforem, pisarz wykrzykuje: „Dobrze, wieś! ale jaka niechlujna! [...]”46. Zaraz jednak dodaje, jakby po namyśle: No tak. - „Samo życie tylko jest zajmujące: to rojenie się azjatyckie - ma w sobie coś z rojenia się robactwa" 47 .

$Z$ listów Sienkiewicza przebija rozczarowanie. Nic go naprawdę nie poruszyło, nie zachwyciło, nie przemówiło do wyobraźni. $Z$ pewnością przydały się wizyty w stambulskim muzeum, gdzie zobaczył świetnie zachowane stroje tureckie z epoki Sobieskiego i nieprzeliczone kolekcje dawnej broni. Krótkie wytchnienie dały Wyspy Książęce oglądane na morzu za gęstą mgłą i cudowny widok na Morze Marmara. Ale humor odzyskał dopiero podczas wycieczki na Wielki Bazar, na którym, jak go zapewniano, spotkać można ludzi z całego świata. W liście do szwagierki, w którym opisuje tę wizytę, nie żałuje szczegółów - zainteresowały go tutejsze zwyczaje handlowe:

\section{\Oprowadza nas po nim malarz Farnet $[\mathrm{t}] \mathrm{i}^{4^{8}}$, Polak, który zna Stambuł doskonale i umie wszystko tanio kupować. - Żebyś też wiedziała Hanem, jak się w tym Bazarze malują rozmaite temperamenty na- rodowe. Turek się nie targuje. Powiada swoją cenę i gdy mu ofiarują mniejszą, podnosi w górę głowę, mówiąc: jok! - nie! Ledwie raczy gadać $\mathrm{z}$ kupującym. Żydzi tak się ujadają jak u nas, a z Grekami cała tragedia: „Dzieci moje umrą z głodu, żona! Chcesz je zabić? Chcesz odpowiadać przed Bogiem? Napluj mi w twarz, jeśli mogę oddać za tę cenę. \\ - Wychodzisz? Czelabi! effendi! monsieur! gospodin! - bierz!"49.}

$\mathrm{Z}$ innych stambulskich zabytków pisarz zobaczył jeszcze Eiub, Fanar i katedrę grecką. Spotkał się także z Achmedem Weffikiem ${ }^{50}$, tureckim dostojnikiem, byłym

46 Ibidem, list 26, s. 216.

47 Ibidem, s. 217.

48 Stefan Farnetti, półkrwi Polak i Włoch, był malarzem na stałe mieszkającym w Stambule.

49 H. Sienkiewicz, Listy, op. cit., t. 2, cz. 1, list 27, s. 224-225.

50 Antoni Zaleski poświęcił mu cały V rozdział swojej książki. Achmed Weffik był komisarzem Porty w Bukareszcie, ambasadorem w Paryżu, prezesem tureckiej Izby Deputowanych, wielkim wezyrem, generalnym gubernatorem Brussy. 
dyplomatą, który zrobił mu szczegółowy wykład na temat pochodzenia narodu tureckiego i - rzecz jasna - przekonywał o jego starożytności i ważności w całym świecie. W jego przepełnionym bogactwem domu pisarz zobaczył, jak wyglądają feudalne relacje pomiędzy wielkim panem a służbą, traktowaną jak niewolnicy, i zakosztował gościnności w iście tureckim stylu. Pojechał także do pałacu w Berlebeju, a w Skutari ${ }^{5 \mathrm{I}}$ obserwował przedziwne obrzędy derwiszy wyjących. Zaleski dokładnie opisał tę wizytę w swojej książce. Nie szczędził szczegółów, nie pominął więc wyrazu niesmaku na twarzy Sienkiewicza, który podczas sesji z derwiszami depczaccymi w transie po chorych niemowlętach (miało im to przywrócić zdrowie), wyszedł zbulwersowany tą prymitywną praktyką. Pisarz zachował natomiast we wdzięcznej pamięci wycieczkę do Kachariatch, gdzie podziwiał dobrze zachowane w świątyni piękne mozaiki (Głowa Chrystusa, Matka Boska z Dzieciątkiem). Wizyta na zabytkowym cmentarzu, znajdującym się w drodze do Skutari (w liście wykrzykuje: „Cudowny”!) wprawiła go w melancholijny nastrój i skłoniła do refleksji na temat tureckiej kultury. Napisał wtedy do Janczewskiej:

\Ktoś powiedział o Turkach, że lud ten żyje w największej przyjaźni ze śmiercią - i mimo woli przychodzi ci na myśl, że te miasta rojne, brudne, nędzne to chwilowe zbiegowisko, chwilowy jarmark ludzkiego pomiotu, a prawdziwe życie ciche i wieczne zaczyna się tam pod cyprysami. - Puvis de Chavannes umiałby to odmalowaćs ${ }^{52}$.

\section{Ex Oriente LuX?}

Powiedzenie, że „światło idzie ze Wschodu”, w świetle Sienkiewiczowskiej relacji mogłoby wyglądać na ironię. Rzecz nie w tym, że podróż nie była satysfakcjonująca - być może wszyscy jej uczestnicy mieli zbyt wielkie oczekiwania? Wydaje się natomiast, że towarzyszyło jej przekonanie o definitywnym fiasku dawnego Imperium, a to, co pisarz tak wnikliwie zauważył, było potwierdzeniem kryzysu, w jakim pogrążyło się państwo osmańskie po dotkliwej porażce w Europie. Tendencja, by w takich właśnie kategoriach (upadku, fiaska, klęski) ujmować te kwestie, u Sienkiewicza ledwie sugerowana, bardzo mocno wybrzmiewa u Zaleskiego, który nie stroni od śmiałych spekulacji na temat przyszłości politycznej Turcji, nazywanej nie bez pewnej satysfakcji „chorym człowiekiem Europy”53.W opisie Pery, dzielnicy

51 Skutari (turec. Üsküdar) - jedna z dzielnic Stambułu, po azjatyckiej stronie Bosforu.

52 H. Sienkiewicz, Listy, op. cit., t. 2, cz. 1, list 28, s. 233.

53 Autorstwo tego określenia przypisuje się Mikołajowi I. 
Konstantynopola, w której na każdym kroku pysznią się pałace przedstawicielstw dyplomatycznych najsilniejszych państw Europy, dziennikarz zastanawia się wręcz, które z nich odegra tutaj decydującą rolę. Nie ma natomiast najmniejszych wątpliwości, że islam jest w odwrocie i tylko patrzeć, kiedy na Świętej Zofii zawiśnie chorągiew z krzyżem.

Czy Konstantynopol przetrwa? Z pewnością - przytakuje dziennikarz: „Bez Turków i ich destrukcyjnych rządów, będzie on zawsze dla samego położenia cudownym miastem południa, lecz już nie «perłą» wschodu" ${ }^{4}$.

Wydaje się jednak, że ludzie Zachodu zdawali sobie sprawę, iż legenda Konstantynopola jest kwestią wielowiekowej idealizacji. W I908 roku Louis Bertrand poświęcił tej sprawie artykuł pod znamiennym tytułem La realité et le mirage, w którym zrelacjonował m.in. swój długoletni pobyt w tym mieście i swoje rozczarowanie, nie wiem, czy nie głębsze niż Sienkiewiczowskie. Podsumował gorzko w pewnym momencie: „Sans nos Byron, nos Théophile Gautier, nos Loti, Stamboul, elle-même ne serait qu'un expression géographique" 55 , przyznając ostatecznie, że „mirage oriental" jest tylko mirażem ${ }^{56}$. Niestety, z dzisiejszego punktu widzenia te poglądy to typowy przejaw optyki kolonialnej.

\section{GrecjA}

W Konstantynopolu drogi podróżników się rozchodzą. Misja Zaleskiego jest skończona, Pochwalski zostaje na dłużej, aby ukończyć portret Ludwiki Gropplerowej, Sienkiewicz zmierza zaś w stronę Grecji na statku „Donnai”, który pływa z Bebek do Aten.

W nocy intensywnie obserwuje morze - z ciemności i mgły powoli wyłaniają się przed nim wyspy. Zachwycony widokami pisze z entuzjazmem do Jadwigi: „Byłem pod pewnym wrażeniem na myśl, że wjeżdżam na Archipelag, o którym Grecy mówili, że jest obrazem nieba, bo tak usiany wyspami jak niebo gwiazdami. Może dlatego dali mu nazwę Arcymorza” 57 . W sprawozdaniu opublikowanym w „Niwie” w I889 roku jako Wycieczka do Aten wykorzysta jeszcze raz opisy, które się tu poja-

54 A. Zaleski, op. cit., s. 245. Autor przytacza anegdotę z książki Maurycego Manna pokazującą, w jaki sposób powstawały wyobrażenia o cudowności Konstantynopola. Pewien angielski lord przypłynął podobno do stolicy Turcji własnym jachtem, zatrzymał się w porcie i długo przyglądał się miastu przez lornetkę. Kilka godzin później odjechał, nie próbując nawet wysiadać na ląd.

55 W tłumaczeniu: „Bez naszego Byrona, Teofila Gautier, Lotiego, Stambuł pozostałby jedynie nazwą geograficzną".

56 L. Bertrand, La realité et le mirage, „Revue des Deux Mondes” 1908, t. 48, s. 141.

57 H. Sienkiewicz, Listy, op. cit., t. 2, cz. 1, list 31, s. 247. 
wiają - rozwinięte i wzbogacone. Zachwyca go krajobraz, ale nade wszystko lejący się z nieba potok światła.

\Wzrok na Archipelagu sięga dalej niż na innych morzach europejskich. Nawet najodleglejsze wyspy widzi się tak czysto i wyraźnie, że można odróżnić niemal każdy załamek skały i zarośla pokrywające zręby wiszarów. [...] Morze i niebo nie tylko są lazurowe, ale i świetliste; gdzie indziej słońce świeci i pali, tu zdaje się przenikać cały krajobraz, wsiąkać weń, nasycać go i stapiać się z nim wyłączając zupełnie wszelki cień. [...] Wszelkie zarysy, na które oko pada, są jednocześnie i niezmiernie wyraźne, i mimo tego miękkie, bo objęte jednym tonem, zarazem przejasnym i łagodnym ${ }^{58}$.

Ziemia, która była kolebką europejskiej cywilizacji, przyprawia go o dreszcz emocji. W liście do Janczewskiej wyznaje:

\Niech, co chce, będzie, człowiek z pewnym wzruszeniem staje na tej ziemi, w obliczu Aten. Jak Innocenty VIII powiedział o Polsce, że w niej każda piędź ziemi krwią męczeńską przesiąknięta, tak można by powiedzieć, że tu każda przesiąknięta myślą grecką, sztuką grecką. Pamiętasz w drugiej części Fausta „Macierze”, owe pierwokształty i pierwowzory wszystkiego, istniejące gdzieś poza światami, poza czasem i przestrzenią, tak uroczyste w swoich nieokreślonych samotniach, że aż straszne. Attyka, nie będąc nieokreśloną ani straszną, jest przecie podobną intelektualną macierzą całej cywilizacji. Bez niej nie wiadomo, gdziebyśmy byli i czymbyśmy byli. Wszystkie inne cywilizacje gubiły się w fantasmagoriach i potwornościach, ona jedna przyjęła za podstawę wiedzy i sztuki świat realny, a jednocześnie umiała $z$ tych pierwiastków czysto realnych wytworzyć najwyższy ład, prawdziwie boską harmonię. Jednym słowem: umiała być boską, nie przestając być ludzką, i to objaśnia całe jej znaczenie ${ }^{59}$.

Refleksje Sienkiewicza o Grecji od początku mają tu postać szczególną, towarzyszą im akceptacja, zdeklarowane uwielbienie, nieskrywany zachwyt. Czytając je, mamy

58 H. Sienkiewicz, Wycieczka do Aten, „Niwa” 1889, nr 1-3. Cyt. wg przedruku: idem, Dzieta, op. cit., t. 44, s. 240.

59 H. Sienkiewicz, Listy, op. cit., t. 2, cz. 1, list 31, s. 248-249. 
wrażenie czegoś doskonale przemyślanego i uformowanego. Obrazy i przeżycia uruchamiają pracę erudycji.

Do Pireusu statek pisarza przypłynął świtem. Dalej, do Aten, które były głównym celem jego podróży, można było dotrzeć koleją, ale on zdecydował się na powóz. Chciał po swojemu, intymnie przywitać się z Helladą. Czytając te opisy, za każdym razem mamy wrażenie, jakby był tam wcześniej. Działają wiedza i wyobraźnia, dlatego skąpany we mgle Akropol wygląda na tak pełen majestatu. Po przybyciu do miasta pisarz nie kryje zaskoczenia - współczesne Ateny wydają się takie piękne:

\ jasne, schludne i wesołe miasto, zupełnie europejskie, ale budujące się wedle dawnych porządków architekturalnych greckich, co mu nadaje pyszny pozór. Wszędzie spostrzegasz kolumny jońskie, korynckie i doryckie, fryzy, które począł rzeźbić człowiek, a dorzeźbia słońce

- relacjonuje Janczewskiej ${ }^{60}$.

W architekturze miasta dostrzega to, co ceni najwyżej - ścisły związek pomiędzy naturą i tym, co jest tworem człowieka. Jego zdaniem jest to podstawowa zasada dobrego funkcjonowania cywilizacji, fundament ładu i harmonii. Nie dostrzega tego, co tak raziło podróżnych mających okazję widzieć Ateny wcześniej - sztuczności miasta niedawno przebudowanego na wzór zachodnich metropoliii ${ }^{61}$. W Atenach pisarz mieszka w samym centrum miasta, w hotelu na rogu placu Konstytucyjnego i ulicy du Stade. Stamtąd wyrusza na codzienne przechadzki, przygląda się ludziom i nowym porządkom, bo Grecja pomiędzy I870 i I89o rokiem stabilizuje się jako państwo nowoczesne. Swoim zwyczajem obserwuje ulice, szukając miejscowego kolorytu. Jest nieco zawiedziony, nie znajdując wśród ludności klasycznego typu urody, znanego ze starożytnych monumentów. Ale brakuje mu także wyrazistych egzotycznych typów i związanej z Orientem malowniczości. Pisze, że dominuje ormiański typ urody, pospolity i nieprzyciągający uwagi. Grecy współcześni - hałaśliwi, cyniczni i leniwi, nie przypominają postaci z dawnych legend, mitów i eposów. Nader często cechuje ich przesadna duma narodowa, granicząca z megalomanią i nieznajdująca pokrycia w rzeczywistych dokonaniach. Sienkiewicz krytycznie

60 Ibidem, s. 251-252.

61 Pisze o tym Božidar Jeziernik: „Ateny utrzymały orientalny charakter aż do połowy XIX wieku, podobnie jak większość greckich miast [...]. Po roku 1834, kiedy siedziba rządu greckiego przeniosła się do Aten, zburzono mury miejskie zbudowane w czasie tureckiego panowania i umożliwiono helleńskiej stolicy rozwój. Niektóre ulice otwarto, poszerzono i wyrównano, zaczęły wyrastać nowe budynki. [...] Do połowy XIX wieku turecka część Aten znikła. Meczety szybko zburzono lub zamieniono je na magazyny. W II połowie XIX wieku na miejscu historycznych Aten pojawiło się nowoczesne «francuskie» albo «południowoniemieckie» miasto z około 50000 mieszkańców" (op. cit., s. 229). 
wypowiada się także na temat greckiego Kościoła. Według niego, to prawdziwe nieszczęście, że kraj o takiej przeszłości należy do schizmy: „Mówię to nie jako fanatyk, ale kult taki posępny, tak zagrzęzły w suchym formalizmie nie przyczyni się nigdy do rozwoju nauk i sztuk" ${ }^{62}$. W jego opinii żadna ortodoksja nie da się zestroić z odczuwaną powszechnie potrzebą modernizacji życia.

Najważniejszą częścią wycieczki Sienkiewicza do Grecji jest zwiedzanie ruin. Pisarz odwiedza Akropol, Areopag, muzeum Hagia Triada, świątynię Zeusa, Stoa i Agorę. Wędrówkę po Akropolu opisuje w liście do szwagierki szeroko, dokładnie, jako szczególne doznanie:

\ Pierwsze wrażenie: ruina, ruina, cisza, śmierć! Kolumny porozsuwane tak [tu rysunek], ściany strzaskane, wyszczerbione, przeświecające na wylot, poobłamywane, nigdzie łokcia swobodnego gruntu, cała przestrzeń zarzucona i zawalona trzonami kolumn, zrębami architrawów, fryzów, obłamami metopów, kapiteli, głazami ścian. Wszystko to narzucone jedno na drugie, obsuwające się, zwieszone, pochyłe, spiętrzone, leżące w dzikim bezładzie, o którym nawet Forum rzymskie nie może dać pojęcia. Przychodzi ci do głowy, że się tu odbyła jakaś straszliwa walka olbrzymów lub olbrzymich sił, od której góra się trzęsła, pękały mury, aż wreszcie runęło wszystko i pozostało tylko zniszczenie.

Więc pierwszym wrażeniem, jakie otrzymujesz, jest wrażenie katastrofy ${ }^{63}$.

W erudycyjności tego zapisu rozpoznajemy jego lektury - Ateny Burnoufa czy bestseller na rynku francuskim Dictionnaire des antiquites Richa. Ale w opisie ukrywa się także ślad emocji, w prywatnej korespondencji bardziej zresztą przekonujący niż w publikacji prasowej, bo bezpośredni:

》Więc siedzisz, patrzysz na to kamienne uroczysko, na potop słoneczny, na zatopione w świetle zręby, złamy, aż wreszcie coś wstaje od ruiny, idzie i wstępuje w Ciebie. Zaczynasz się jednać z tym światem, później zlewać, w końcu po prostu kamieniejesz. Wtedy Ci jest dobrze,

62 H. Sienkiewicz, Listy, op. cit., t. 2, cz. 1, list 31, s. 254-255.

63 Ibidem, list 32, s. 261.

Pisząc o katastrofie, podróżnik nie tylko konstatuje upadek dawnych wierzeń i dawnej kultury greckiej, ale także stan zabytków - w czasach Sienkiewicza fatalny. Ulegające stopniowej dewastacji zabytki starożytnej Grecji stanowiły widok godny pożałowania. Idea ochrony dziedzictwa światowego dopiero się zaczynała. Zwiedzanie, zwłaszcza samotne, było praktycznie niemożliwe z uwagi na napady, kradzieże, a nawet porwania. 
bo wchodzi w Ciebie ogromny spokój, ale to taki ogromny, jaki tylko może mieć kamień i ruina. [...] Prostota, spokój, powaga i prawdziwie boski ład - oto one ${ }^{64}$.

Ten zapis musi być gwoli sprawiedliwości skonfrontowany ze współczesnym komentarzem przywoływanego wcześniej badacza. Nikt nie ma wątpliwości, że zwiedzanie Aten to przede wszystkim wizyta na Akropolu. Jak pisał o nim Christopher Wordsworth - „zawsze podziwianego, naśladowanego i niezrównanego w urodzie" ${ }^{65}$, ale... I tu warto posłuchać Jeziernika:

\Aby ujrzeć je w pełnej okazałości, trzeba by było jechać tam przed końcem XVII wieku, w towarzystwie Francisa Vernona czy Sir George'a Whelera ${ }^{66}$, kiedy świątynia Ateny stała jeszcze nienaruszona. Poradzono by nam wtedy wziąć ze sobą ze trzy oki ${ }^{67}$ kawy i przekupić nimi władze, by wydały zgodę na odwiedzenie Akropolu. Ci bardziej ciekawscy mieliby jednak problemy, gdyby chcieli na przykład poczynić tam dokładne pomiary, miejsce było bowiem siedzibą garnizonu tureckiego $[\ldots]^{68}$

- a Turcy, jak pisze następnie badacz, nie byli skłonni wpuszczać tam nikogo. W jego dalszej opowieści o Atenach napięcie rośnie niczym w filmach Hitchcocka. To dzieje przechodzenia miasta i jego zabytków $\mathrm{z}$ rąk do rąk, to historia bezceremonialnego przekształcania go w twory kolejnych religii i cywilizacji, wreszcie - cynicznej grabieży i łupiestwa, dokonywanych często pod przykrywką nauki i ochrony wspólnego dziedzictwa. Grasantami byli nie tylko poganie, ale także reprezentanci wysoce rozwiniętych społeczeństw zachodniej Europy, tą metodą zapełniający sale swych dostojnych muzeów, którymi teraz się chlubią. Jak pisze Jeziernik:

\Z Zachodni miłośnicy sztuk udzielali się pilnie nie tylko na Akropolu. Na początku XIX wieku grupa brytyjskich podróżnych natrafiła

64 H. Sienkiewicz, Listy, op. cit., t. 2, cz. 1, list 32, s. 262.

65 B. Jeziernik, op. cit., s. 229. Autor powołuje się tu na: Ch. Wordsworth, Greece: Pictorial, Descriptive, and Historical, London 1839.

66 Ibidem. Chodzi o listy Francisa Vernona z podróży z Wenecji, przez Istrię, Dalmację i Grecję do Smyrny, w: Rev. John Ray, A Collecton of Curious Travels and Voyages. Containing Dr. Leonhardt Rauwolf's Journey Into the Eastern Countries II (London 1738) oraz pracę George'a Whelera, A Journey into Greece. In the Company of dr Spon of Lyons (London 1682).

67 Oka (właśc. okka) - dawna miara masy przyjęta w Imperium Osmańskim. 1 okka $=2$ i 11/4 funta, czyli $1,282 \mathrm{~kg}$.

68 B. Jeziernik, op. cit., s. 230. 
w Mistrze na Peloponezie na kilkanaście fragmentów pięknie żłobkowanych kolumn, które kiedyś były częścią świątyni Demeter. Obok nich leżała rozbita na kawałki tablica z napisem. Podobno zniszczyli ją dwaj Francuzi, którzy nie potrafili jej odczytać i połamali ją na złość brytyjskim podróżnikom ${ }^{69}$.

Czy Sienkiewicz był świadom tego, jak wiele zniszczeń dokonał tu człowiek? Wydaje się, że tak. W kontemplacji ruin zawsze ukrywa się melancholia i zaduma na przeszłością. Pisarz już w Ameryce widział, jak w imię przyszłości niszczy się pierwotne kultury. Myślę też, że zdawał sobie sprawę z tego, że to, co ogląda, jest ledwie nikłą częścią tego, co tak pięknie sobie wyobrażał, i co urosło nie tylko przecież w jego wyobrażeniach w prawdziwy mit o korzeniach Europy. To w greckich ruinach ujrzał tradycyjnie kojarzone z Orientem mistyczne światło i boski ład. Cudowna symetria boskiego i ludzkiego była - jego zdaniem - najczystszą emanacją greckiej sztuki:

\ Mitologia grecka była czcią sił przyrody, czyli elementarnym panteizmem, ale w duszy Greka artysta przeważał zawsze nad filozofem, więc naprzód poeci ubrali zjawiska w ciała i uczucia ludzkie, później przyszła sztuka plastyczna i stąd narodziła się taka cudowna baśń kamienna. - Atena (do której z powodu Odysei mam szczególne nabożeństwo) umiała też sobie wybrać miejsce na stolicę, bo co to za tło dla tych świątyń i posągów! Z jednej strony widać morze, które w tym przezroczystym powietrzu wydaje się tuż! z drugiej - całą Attykę jak na dłoni: góry Hymetu, dalej Pentelikon, z którego brano marmury na świątynie: na północ Parnas, a ku południo-zachodowi, ku Cieśninie Salamińskiej, Daphni. Nad wszystkim niebo ciągle pogodne i orły, których krakanie przerywa do dziś dnia ciszę na Akropolu ${ }^{70}$.

Najbardziej zastanawiające jest jednak, że fantazmat przedkładał nad rzeczywistość. Choć Grecja była jego odwiecznym celem i marzeniem, nie wracał z niej, jak wynika z listu do szwagierki, szczęśliwy. Mijał rok od śmierci żony; podróżowanie, miast ukoić jego nerwy, mocno go rozdrażniło. Wracał przez Italię, zatrzymując się w drodze powrotnej w Brindisi oraz w Neapolu. Doczekawszy się tam powrotu Kazimierza Pochwalskiego z Konstantynopola, razem z nim intensywnie zwiedzał południowe Włochy. Razem zrobili wycieczkę na Wezuwiusz, oglądali Pompeje,

69 Ibidem, s. 232.

70 H. Sienkiewicz, Listy, op. cit., t. 2, cz. 1, list 32, s. 263-264. 
Błękitną Grotę (Grotta Azzurra), Sorrento, Capri, Castellammare. Znowu zatem zanurzył się w Elizjum kultury. Ostatecznie zatrzymał się w Rzymie, gdzie czekało go spotkanie z Piusem Welońskim i Stanisławem Smolką ${ }^{71}$.

\section{LIST: GATUNEK I ANTROPOLOGIA}

W tytule mego tekstu znalazło się określenie „płynność gatunkowa”, podkreślające niewielkie $\mathrm{w}$ istocie różnice, jakie w tym konkretnym przypadku rysują się pomiędzy dokumentem osobistym, jakim jest dziennik czy korespondencja artysty, a listem z podróży, który był/jest traktowany jak publiczna wypowiedź o charakterze sprawozdawczym (reporterskim). Różnice niewielkie, jeśli pominąć kwestie związane $z$ cenzurą i powszechnym stosowaniem autocenzury, bo te zawsze są duże, nie wyłączając z tego Sienkiewicza. Wiele uwag, które otwarcie komunikuje on w listach prywatnych - dotyczy to przede wszystkim spraw politycznych - nie mogło się pojawiać i nie pojawiało się w korespondencjach prasowych lub przeznaczonych do druku.

Co zaś do genologii, można by powiedzieć tak: jeśli coś publikowano w prasie i spełniało to funkcję sprawozdania z jakiegoś miejsca, podróży czy wizyty, to niezależnie od tego, czy było nacechowane prywatnością, czy nie, i jakie inne cechy gatunkowe miało - felietonu, eseju, poematu etc. - odbierane było zawsze jako mająca oryginalne cechy podmiotowości autorskiej wypowiedź dokumentarna. Wypowiedź taka w pełni korzystała $\mathrm{z}$ wielkiej stylistycznej wspólnoty ${ }^{72}$, cechującej w wieku XIX wszystkie teksty o charakterze publicystyczno-literackim, właściwie ciągle formujące swoją gatunkową postać (bo jednak nie kanon ${ }^{73}$ ); w zasadzie pozbawiano ją jedynie retoryki intymności, która stanowiła jej pierwotną ramę modalną. Zachowując treść przekazu, czyli to, „co się sprawozdaje”, publikowany list czy korespondencja wyzbywały się wskaźników poufałości, wtrętów konwersacyjnych i tych wszystkich elementów, które mogłyby pomóc w bezpośredniej identyfikacji podmiotu autorskiego i adresata. Bardzo dobrze widać to na przykładzie planowanej pierwotnie jako odczyt Wycieczki do Aten, która będąc prymarnie sprawozdaniem

71 Pius Weloński (1849-1931) malarz i rzeźbiarz polski na stałe zamieszkały w Rzymie.

Stanisław Smolka (1854-1924), historyk polski, organizator tzw. ekspedycji rzymskich (1886-1901), których celem było zapoznanie się z polskimi archiwaliami w Watykanie. Obaj zaprzyjaźnieni z Sienkiewiczem.

72 Z. Jarosiński, Tekst u̇̇ytkowy i tekst literacki w XIX w., ,Teksty” 1975, nr 4.

73 Kanon to jednak coś, co pozostaje niezmienne w swych właściwościach; gatunki prasowe czy szerzej - medialne zawsze zachowały pewien rodzaj otwartości. 
z podróży, jest także popisem sztuki syntezy i świadectwem wysokiej kultury jej autora.

Jego opowieść, pozbawiona elementów bezpośredniej identyfikacji, w korespondencji prywatnej rozpisana na kilkanaście listów, niekiedy pokaźnych rozmiarów, a więc i treściowo rozproszona, w postaci tekstu prasowego inaczej sfunkcjonalizowana, ostatecznie stawała się zatem kilkustronicową wypowiedzią z silnie zaznaczonym podmiotem autorskim, własnym stylem i koncepcją opowiadania. To, że Sienkiewicz miał pomysł na jej opracowanie, ujawnia list do Janczewskiej z 8 listopada I886 roku, w którym pisarz stwierdza wprost: „Co do odczytu, nie będzie to opis podróży, ale coś w rodzaju obrazów z podróży Heinego, zatem jakby feljeton pełny najrozmaitszych refleksji" "74. Rzeczywiście, otrzymaliśmy coś w rodzaju dłuższego felietonu: ze swobodnym tokiem narracji, refleksjami o polityce, obyczajach i roli tradycji, z elementami humoru, anegdoty, ale i niestroniącego od zadumy.

Wszystko to, co wcześniej mówiliśmy na temat orientalnych miraży i rozczarowania, w korespondencji publikowanej w prasie uległo kondensacji i stało się nieomal kwintesencją rozproszonych wcześniej uwag i wrażeń, czymś w rodzaju artystycznego podsumowania. Sienkiewicz, wypływając z Konstantynopola wieczorem, ma przed sobą jedyne w swoim rodzaju widoki:

\section{》Dżdżyste od kilku tygodni niebo wypogodziło się na koniec zupełnie i zarumieniło się wspaniałą zorzą wieczorną. Pobliski brzeg azjatycki zalany był światłem; Bosfor i Złoty Róg wyglądały jak olbrzymie ogni- ste wstęgi, a Pera, Galata i Stambuł, ze swymi wieżami, z kopułami i minaretami meczetów, tonęły w złocie i purpurze. [...] Chwilami zdawało się, że cały gród zaczarowanych pałaców wisi w powietrzu, to znów byłem pod wrażeniem takiego majestatu, ogromu i potęgi, jak gdyby z tego miasta dotychczas jeszcze szedł strach na całą Europę i jakby w wieży Seraskieratu dziś, tak samo jak ongi, ważyły się losy świata ${ }^{75}$.}

Szukając zaś równowagi pomiędzy doświadczeniem iluzji i deziluzji, pisarz zdobywa się na dystans i bierze te doświadczenia w artystyczny nawias:

74 H. Sienkiewicz, Listy, op. cit., t. 2, cz. 1, list 30, s. 239-240. Odczyt pt. Wspomnienia z Aten Sienkiewicz zaprezentował w Krakowie 25 marca 1887 roku. Tekst Heinego stanowiący dla niego wzorzec to Obrazy z podróży (Die Reisbilder), wydane w Polsce w przekładzie L. Kaczyńskiej i A. Mieleszki-Maliszkiewicza jako Obrazy z podróży, Warszawa 1879, t. 1-4. Gatunkowo tekst reprezentuje pogranicze dziennika z podróży i felietonu, zawiera także fragmenty poezji.

75 H. Sienkiewicz, Wycieczka do Aten, w: idem, Dzieta, op. cit., t. 44, s. 236-237. 
\ te blaski zorzy wieczornej, te morza płonące, pałace i minaret, skąpane w purpurze i złocie, są czymś zupełnie równie rzeczywistym i realnym jak psy zdechłe leżące dziesiątkami po ulicach Stambułu ${ }^{76}$.

Charakterystyczny dla Sienkiewicza ton, pełen paradoksu, sprzyja sugestii, że oto sprzeczność jest istotą Wschodu i tworzonej tu cywilizacji, która znalazła się w momencie poważnej zmiany politycznej i kulturowej. Dzieje ludzkości zawsze pochłaniają miliony anonimowych ofiar, stając się krwawym spektaklem przemocy. Przepływając Dardanele, pisarz nawiązuje więc refleksją do zakończonej wizyty na Bałkanach:

\section{\I znów przychodzi na myśl pytanie, które na Wschodzie przychodzi nie- mal wszędzie - w Ruszczuku, w Warnie, w Burgas, w samym Stambule: zali to są te kraje, o które wylało się tyle krwi ludzkiej, że można by nią całą cieśninę wypełnić? Zali dla tych miast, na wpół zapadłych w ruinę, zamieszkanych przez na wpół żebraczą ludność, dla tych jałowych pól, bezpłodnych skał wydają się miliony, utrzymują się olbrzymie armie - i życie upływa pokoleniom ludzkim w niepewności dnia i godziny? ${ }^{37}$}

Zostawiwszy na boku spekulacje natury politycznej, Sienkiewicz zmierza wreszcie ku brzegom Hellady i powtarza wszystko to, co z takim upojeniem zapisywał w prywatnych listach. Wrażenia z pierwszego spotkania z ziemią Greków, oglądanie miasta, uwagi na temat mieszkańców i ich charakteru w korespondencji prywatnej zapełniające kilka listów, tu przekomponowano i ujęto w nową, znakomicie zestrojoną całość. Jest w niej oczywiście miejsce na prywatne przeżycia w ruinach i jest specyficzne podsumowanie tego, czym są Ateny i czym jest Grecja dla ludzkości, bez której, jak pisał wcześniej: „nie wiadomo kim byśmy byli i gdzie byśmy byli”. W Wycieczce Sienkiewicz zdobywa się jednak na szerszą niż w prywatnej korespondencji argumentację powodów, dla których nastąpiło odrodzenie Grecji po wiekach dominacji tureckiej:

\Nie sam tylko interes polityczny nakazywał wskrzeszenie Grecji, ale dla Europy był to dług do spłacenia, była to kwestia po prostu wstydu. [...] Gdyby nie owo olbrzymie credit, które na rachunek Grecji zapisała cywilizacja, gdyby nie jej sława i czyny, gdyby nie pieśni Homera, nie wspomnienia Maratonu i Salaminy, nie te ruiny akropolskich arcy- 
dzieł, baszowie do tej pory mieliby swoje haremy w Erechtejonie, a ze szczytów Akropolis powiewałaby flaga Proroka. Więc gdy powiem, że Grecję dzisiejszą odbudowali Homer, Milcjades, Leonidas, Temistokles, Fidias, Perikles i inni bohaterowie lub geniusze tej miary, nie będzie to figurą retoryczną, ale dziejową prawdą. Pracując dla sławy swego narodu, pracowali, nie wiedząc o tym, dla jego odrodzenia tacy nieśmiertelni agenci sprawili, że Grecja żyje $7^{78}$.

Zupełnie pewne jest, że opowieść o Grecji - dawnej i nowej - jest dla Sienkiewicza okazją, aby przypomnieć swoim rodakom, z którymi porozumiewa się niezależnie od cenzuralnych ograniczeń, jaką ozdrowieńczą mocą dysponuje kultura i jak potężne kryją się w niej siły.

Z porównania obu wycieczek, Zaleskiego i Sienkiewicza, wyciągnąć można wiele wniosków, choć w pierwszym rzędzie podkreślić trzeba całkowitą odmienność ich celów. Wycieczkę Zaleskiego, bardzo ciekawą z uwagi na wszechstronne zainteresowania publicysty i jego poznawcze intencje, wypełnia ogrom szczegółów, dziennikarska buchalteria i czasem dość ryzykowne spekulacje polityczne, na tyle jednak wyciszone, żeby - dla przykładu - nie eksponować totalnej klęski Rosji w Bułgarii jesienią r 886 roku. Znamienne - w Konstantynopolu niczym niekrępowany używa ile wlezie na konającym trupie tureckiego imperium. Co innego Sienkiewicz - w listach pisanych do subtelnej i wymagającej adresatki nie szczędzi szczegółów, ale zasadniczo w kwestiach politycznych nie rozszczepia włosa na czworo. W publikacji prasowej natomiast unika tego, co ryzykowne - i zupełnie rezygnuje z części bałkańskiej. Dlaczego? Dlatego że... musiałby napisać prawdę, a tej nie zaakceptowałby żaden $\mathrm{z}$ warszawskich cenzorów. Wybrał więc... kulturowy eskapizm. Pisze o greckiej architekturze, nowych porządkach, sztuce i jej nieśmiertelnej zdolności odradzania narodów.

$\mathrm{Na}$ koniec jeszcze jedna uwaga, bynajmniej nie marginalna. Dzisiejsza refleksja badawcza obejmująca formy dokumentarne w sposób znamienny przesunęła swoje zainteresowania $\mathrm{z}$ problemów genologicznych na antropologię̧79. Zapewne słusznie, ponieważ dziedzina dokumentaryzmu, przeżywająca w naszych czasach spektakularny rozkwit i mnożąca formy o charakterze hybrydalnym, coraz skutecz-

78 Ibidem, s. 259. Fragment z listu do Janczewskiej prezentujący cytowany tu pogląd brzmi tak: „Jest to jedyny przykład państwa, które wskrzeszono dlatego tylko, że 2000 lat temu wydało niezrównaną literaturę i sztukę. Zresztą nic nikomu politycznie na wskrzeszeniu Grecji nie zależało, więc właściwie: wskrzeszono ją dla Homera, Sofoklesa, Fidiasza i Arystotelesa, etc." (H. Sienkiewicz, Listy, op. cit., t. 2, cz. 1, list 30, s. 239).

79 Zob. G. Grochowski, Pytania o fikcjonalna proze dyskursywna, w: Polonistyka w przebudowie, pod red. M. Czermińskiej, Kraków 2005 oraz P. Zajas, Jak świat prawdziwy stat się bajka. O literaturze niefikcjonalnej, Poznań 2011. 
niej zaciera różnice pomiędzy literaturą i publicystyką, prawdą i fikcją, nie ustając w poszukiwaniu sobie tylko właściwego sposobu opowiadania o ludzkiej kondycji. $Z$ tego zaś punktu widzenia ważniejsze wydaje się zatem, co tekst w ogóle mówi o opisywanym świecie, jak to robi i dlaczego. Ważne jest także, z jakim bagażem przystępujemy do opisu innych kultur niż nasze.

Wydaje się, że Sienkiewicz był świadom tych uwarunkowań. W Wycieczce do Aten chyba nieprzypadkowo pojawia się fragment, w którym pisarz komentuje frywolny ton opowieści Edmonda Abouta, podkreślającego, jak bardzo współcześni Grecy różnią się od swoich przodków - twórców europejskiego dziedzictwa kulturowego ${ }^{80}$. Przyznając „wnukowi Woltera” pewną rację, zastrzega jednak:

\ w tym, co mówi wspomniany autor i inni nowsi o Grekach, musi być niewątpliwie wiele przesady, a może jeszcze więcej nieporozumienia. Przede wszystkim każdy [...] podróżnik przynosi ze sobą gotową miarę etyczną, bardzo rozległą, bo będącą wpływem cywilizacji zachodniej i jej wyrobionej kultury moralnej. Owóż taką skalą mierzą społeczeństwo, które dopiero przed niedawnym czasem wydostało się z niewoli, istotnie sromotnej i upadlającej, a mierzą tym bezwzględniej, że chodzi o obcych, nie o swoich. Zapominają także i o tym, że jak na przykład pojęcia honoru i rycerskości były obce światu starożytnemu, tak samo musiała istnieć cała sfera pojęć moralnych obcych ludom wschodnim; że ludy, zwłaszcza podbite, jak byli Grecy, nie miały, ściśle mówiąc, przez długi czas żadnych pojęć, a rządziły się, bo się musiały rządzić, jeno zwierzęcym, samozachowawczym instynktem. Instynkt ów był dla nich miarodajnym i rozstrzygał zarówno w kwestiach etyki, jak i logiki ${ }^{8 \mathrm{r}}$.

Mierzenie jedną miarą wszystkich i szafowanie łatwymi ocenami na temat ucywilizowania i dzikości to jeden z najczęstszych - jak pisze dalej - wątków wspólczesnego dyskursu politycznego. Jeśli nie skorzystamy z szansy, jaką daje wiedza i doświadczenie - także to podpatrzone u innych - na zawsze pozostaniemy „dzikimi”. Greków przed utratą zmysłu moralnego chroni wskrzeszony od niedawna patriotyzm polityczny i kulturowy, który stawia na pierwszym planie przyszłość cudem odzyskanej ojczyzny.

80 Chodzi o książkę Edmonda Abouta La Grèce contemporaine, Paris 1854.

81 H. Sienkiewicz, Wycieczka do Aten, op. cit., s. 250. 
Tak oto lekcja grecka kolejny raz stawała się lekcją dla Polaków, a Sienkiewicz-podróżnik wykazywał się nie tylko znawstwem polityki, ale i wrażliwością antropologiczną.

\section{Bibliografia:}

\section{BibliogRAFIA PODMIOTOWA:}

Sienkiewicz H., Listy, pod red. J. Krzyżanowskiego, oprac. M. Bokszczanin, konsult. M. Korniłowicz, t. 2, cz. 1-3 (listy do Jadwigi i Edwarda Janczewskich), Warszawa 2009;

Wycieczka do Aten, „Niwa” 1889, nr 1-5, w: idem, Dzieła, pod red. J. Krzyżanowskiego, t. 44, Warszawa 1950;

Mieszaniny literacko-artystyczne (I), w: Dzieta, pod red. J. Krzyżanowskiego, t. 50, Warszawa 1950;

A. Zaleski, Z wycieczki na Wschód. Notatki dziennikarza. Bukareszt. Ruszczuk. Warna. Konstantynopol, Warszawa 1887.

\section{BibliogRAFIA PRZEDMIOTOWA:}

De Amicis E., Konstantynopol. Wspomnienia z podróży, tłum. M. Siemiradzka, Warszawa 1879;

Bertrand L., La realité et le mirage, „Revue des Deux Mondes” 1908, t. 48 ;

Berman M., "Wszystko co state rozplywa się w powietrzu”. Rzecz o doświadczeniu nowoczesności, thum. M. Szuster, Kraków 2015;

Bokszczanin M., Listy Sienkiewicza do Jadwigi Janczerwskiej, w: H. Sienkiewicz, Listy, pod red. J. Krzyżanowskiego, oprac. M. Bokszczanin, konsult. M. Korniłowicz, t. 2, s. 5-111;

Brzostek B., Paryże Innej Europy. Warszawa i Bukareszt, XIX i XX wiek, Warszawa 2015;

Grochowski G., Pytania o fikcjonalna proze dyskursywna, w: Polonistyka w przebudowie, pod red. M. Czermińskiej, Kraków 2005;

Jedlicki J., Jakiej cywilizacji Polacy potrzebuja, Warszawa 1988;

Jeziernik B., Dzika Europa. Batkany w oczach zachodnich podróżnikórw, tłum. P. Oczko, Kraków 2007;

Krzyżanowski J., Niedrukowane listy Sienkiewicza. Z podróży do Hiszpanii,„Kurier Warszawski” 1931, nr 1;

Sztachelska J., Henryk Sienkiewicz. Życie na walizkach, Warszawa 2017;

Mity sienkiewiczowskie i inne szkice tylko o nim, Warszawa 2017;

Zajas P., Jak świat prawdziwy stat się bajką. O literaturze niefikcjonalnej, Poznań 2011.

SŁowa KLucze: list z podróży, cenzura, Henryk Sienkiewicz, polityka, dziedzictwo kulturowe 


\section{Jolanta Sztachelska}

From the trip to the East. About a diffERent Europe and a fluctuation of A LETTER AS A GENRE IN THE JOURNEY CORRESPONDENCE OF HENRYK SiENKIEWICZ

The article refers to Sienkiewicz's journey to the East in Autumn i 886 and the writings remaining after that trip: private correspondence - letters to Jadwiga Janczewska (1886) and an account of the journey published in the Warsaw press entitled Wycieczka do Aten [A trip to Athens], “Niwa” 1889, no. I -3 (Dzieta, v. 44, Warsaw 1950). An additional text used in the article is a memoir written by Antoni Zaleski from the same journey entitled $Z$ wycieczki na Wschód. Notatki dziennikarza [From the trip to the East. Notes of a journalist], Warsaw I887.

The article highlights different aims of the journey that both of the authors had and confronts their specific visions of "other", "wilder" Europe - the Balkans and Greece, which are created anew after hundreds of years of Turkish captivity. Both of the correspondences contain interesting remarks on politics, culture and otherness. In the last part of this article the author pays attention to the fluctuations as a genre of a private letter and a letter form a journey, published in press, and also indicates to the anthropological sensitivity of the authors of correspondence.

KEY words: letters from a journey, Henryk Sienkiewicz, politics, cultural heritage 